УДК 351.86: 340.137(477)

Іващенко А. М., к.т.н., доцент (ORCID 0000-0002-8131-5463);

Семененко В. М., к.т.н., с.н.с. (ORCID 0000-0001-5774-0868);

Полякова О. В.

(ORCID 0000-0003-4370-2187)

Центр воєнно-стратегічних досліджень Національного університету оборони України імені Івана Черняховського, Київ

\title{
Оцінювання сценаріїв протидії гібридній війні у воснній сфері
}

\begin{abstract}
Резюме. Досліджуються окремі сценарії протидії гібридній війні у воєнній сфері та контексті повного спектру операцій

Ключові слова: війни нового типу, гібридні війни, протидія, оборонне планування, повний спектр операцій, сценарії, результативність.
\end{abstract}

Постановка проблеми. Наприкінці XX - початку XXI століття глобалізація та інформаційно-технологічна революція стали інтеграторами класичних i нових форм, засобів, методів і технологій війни. Набули поширення гібридні війни (Hybrid Warfare), які пов'язані із збільшенням кількості суб'єктів, їх різними комбінаціями, проведенням декількох фаз конфлікту одночасно, змінами у співвідношенні воєнних i невоєнних засобів досягнення політичних цілей. Проте характер війни нового типу обумовлює необхідність врахування під час проведення оборонного планування особливостей воєнних аспектів сценаріїв протидії, уточнення $\mathrm{i}$ доповнення таких сценаріїв.

Аналіз основних досліджень i публікацій. Аспектам гібридної війни присвячена значна кількість досліджень як провідних аналітичних центрів світу $-R A N D$ Corporation, SIPRI в Стокгольмі, IISS в Лондоні, Європейського центру їм. Дж. Маршалла, так i низки вітчизняних науковців - В. Горбуліна, Г. Перепелиці, $€$. Магди та інших. Водночас, не зважаючи на те, що цей термін використовується в стратегічних документах HATO, СC та країнах-членах цих організацій, теорії сучасної воєнної конфліктології і практики оборонного планування, проблема протидії гібридній війні не достатньо теоретично обгрунтована i потребує подальшого вивчення.

Мета статті. На основі аналізу особливостей воєнних аспектів обгрунтувати доповнення сценаріїв протидії гібридній війні багатопрофільною інтегрованою операцією військових і невійськових сил та засобів.
Виклад основного матеріалу. Війни нового типу, побудовані на поєднанні різних форм i способів збройної боротьби, породжують різні ії визначення: багатовимірні, мережеві, асиметричні, безконтактні, проксі, інформаційні, економічні та інші. Кожне 3 цих визначень відображає переважно один аспект протиборства, але жодне 3 них не характеризує війну нового типу загалом. Спроба об'єднати різнорідні визначення в одному привела до виникнення поняття “гібридна війна", яке часто використовується, однак вкладають у нього різні сенси. Різні підходи надають поняттю “гібридна війна" високий ступінь нестійкості, не дають змоги включити його в існуючу класифікацію війн і конфліктів та обгрунтувати сценарії протидії.

Уперше про необхідність розроблення сценаріїв протидії гібридним війнам заявлено у підсумковій декларації саміту НАТО в Уельсі 2014 р. (Wales Summit Declaration), яка віднесла до гібридних війн проведення широкого спектра прямих бойових дій $i$ спеціальних операцій, які здійснюються за єдиним планом збройними силами, партизанськими та іншими іррегулярними формуваннями за участю різних цивільних компонентів. Реалізація декларації знайшла відображення у Плані дій із забезпечення готовності (Readiness Action Plan).

Саміт у Варшаві 2016 р. розглянув потенційні сценарії протидії гібридній війні, кібератакам, інформаційним війнам, дестабілізації ситуації всередині окремих країн за допомогою прихованого впливу, своєчасного виявлення і реагування на нетрадиційні методи ведення війни, запобігання повномасштабній неядерній воєнній загрозі, можливості 
виконання Альянсом статті 5 Вашингтонського договору 1949 р. в нових умовах [1].

У прийнятій в Брюсселі у 2018 р. “Заяві за підсумками саміту" визначені конкретні сценарії протидії гібридній війні, включно 3 процедурами приведення в дію статті 5 Вашингтонського договору, як i в разі традиційної війни. Для партнерів запропоновані такі сценарії, як направлення груп підготовки до протидії у гібридній війні (Joint Multinational Training Group), підтримка i розвиток спроможностей сектору безпеки i оборони (Security Force Assistance), розміщення Сил швидкого реагування [2]. Метою цих сценаріїв $\epsilon$ надання адресної цільової підтримки союзникам у протидії гібридній війні. Важливе місце відводиться посиленню співпраці між ЄС і НАТО у боротьбі з гібридними загрозами [3].

Національна воєнна стратегія США 2015 p. (The National Military Strategy of the United States of America) визначає як поняття "гібридні конфлікти", так і інтегровану воєнну стратегію (Integrated Military Strategy) протидії.
За результатами багаторічної дискусії, Міжнародний інститут стратегічних досліджень у Лондоні запропонував таке визначення терміна "гібридна війна": “Використання військових $i$ невійськових інструментів в інтегрованій кампанії, яка спрямована на досягнення раптовості, захоплення ініціативи та отримання психологічних переваг для використання в дипломатичних діях, маситабних і стрімких інформаційних, електронних та кібер-операціях, прикриття і приховування військових і розвідувальних дій у посднанні з економічним тиском" [4]. Це визначення точно відображає ключову особливість гібридних воєн від традиційних воєнних конфліктів, необхідну для обгрунтування сценаріїв протидії.

Отже, центральним аспектом гібридної війни залишається збройна боротьба. Інші аспекти направлені на забезпечення збройної боротьби і разом утворюють складну гібридну систему (рис. 1), дослідження якої передбачає декомпозицію i проведення аналізу окремих підсистем. Однак невизначеність процесів протиборства, нечіткість етапів гібридної війни, потребує подальшого уточнення іiі сутності та пошуку принципово нових сценаріїв протидії.

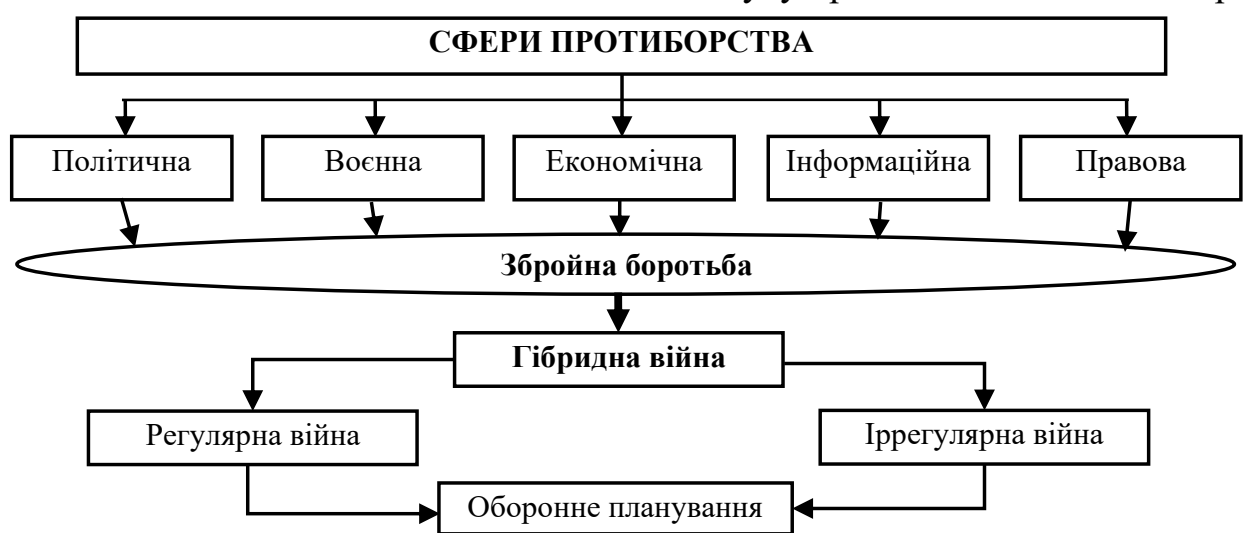

Рис. 1. Концептуальна модель гібридної війни

Так, наведені поняття "гібридної війни" не містять прямого визначення місця, засобів, стратегіï i тактики іï ведення, що робить неможливим застосування цього поняття в оборонному плануванні. Через це в сучасних системах оборонного планування [4] поняття “гібридна війна" замінюється на два регулярні або традиційні (Regular Warfare) та іррегулярні війни (Irregular Warfare). На основі цих понять розробляються сценарії розвитку існуючої і майбутньої оперативної обстановки, на основі яких здійснюються розрахунки наявних i необхідних спроможностей. Поєднання двох основних типів війн визначаються як “війни нового типу" (New Generation War) або “військові операції повного спектру” (Full Spectrum
Operations). Складовими сценаріїв протидії розглядаються: операція об'єднаних сил, дії сил спеціальних операцій, операція 3 надання міжнародної (коаліційної) воєнної допомоги, операція міжнародних сил за мандатом $\mathrm{OOH}$, дії сил територіальної оборони, загальновійськова операція. Такий підхід дає змогу відсунути на другий план розбіжності численних визначень гібридної війни і зосередитися на практичних питаннях оборонного планування. Водночас, проблемним питанням залишається недосконалість системи раннього виявлення гібридних загроз, визначення їх джерел і суб'єктів - ініціаторів.

Сценарії протидії гібридній війні, як багатовимірному конфлікту, не передбачають нанесення основного та допоміжних ударів по 
противнику, а будуються на врахуванні зовнішніх i внутрішніх факторів, особливостей та відповідності показникам результативності протидії.

До зовнішніх факторів, які визначають особливості воєнних аспектів сценаріїв, належать забезпечення протидії: регулярним збройним силам, іррегулярним підрозділам, прихованим насильницьким діям, суспільнополітичним підривним акціям, організації політичних переворотів, прихованих насильницьких дій; спробам встановлення стратегічного контролю над системою забезпечення державної безпеки і прийняття політичних рішень; окупації території i захоплення ресурсів; узгодженим точковим впливам на ключові елементи системи національної безпеки по всій території різновидовими (різновідомчими) тактичними угрупованнями противника, які керуються 3 єдиного стратегічного центру, тактичними одиницями можуть бути не тільки регулярні частини i підрозділи, а й різнотипні іррегулярні формування, приватні військові компанії, і цивільні структури (наприклад, організації 3 галузі високих технологій); загрозі переходу гібридної війни у регулярну фазу, що пов'язано з недостатністю звичайних оборонних спроможностей, які необхідно посилити в інтересах звичайного стримування; розв'язанню воєнного конфлікту внаслідок помилкових оцінок розвитку воєнно-політичної обстановки; імовірним $є$ воєнний конфлікт унаслідок спланованого або випадкового інциденту (провокації); втягування суб'єкта протиборства у регулярну війну через функціонування на національній території окремих груп сепаратистів, які контролюються суб'єкта протиборства, прагнення не допустити поразки цих сил викликає ескалацію регулярних бойових дій до широкомасштабного звичайного конфлікту або ядерної війни.

До внутрішніх факторів, які визначають воєнні аспекти сценаріїв протидії, належать: проведення державою незалежної зовнішньої політики, спрямованої на захист суверенітету i національних інтересів; наявність на території держави цінних природних ресурсів; розташування держави на маршрутах постачання енергетичних ресурсів і важливих транспортних комунікацій; стратегічне положення країни як зручного плацдарму для агресії проти піi сусідів; нестабільна внутрішньополітична ситуація, пов'язана 3 протистоянням владних еліт, корупцією, соціально-економічними, етнічними, релігійними протиріччями, демографічними проблемами.

До особливостей воєнних аспектів сиенаріїв протидї гібридній війни належать: лінійна послідовність етапів реалізації трансформується в нелінійну; знецінення ресурсів, які має суб'єкт протиборства, через втрати політичної, воєнної, економічної інформаційної і правової якості цих ресурсів; операції повного спектру доповнюються багатопрофільними інтегрованими операціями військових і невійськових сил та засобів, які включають військові заходи прихованого характеру, дії сил спеціальних операцій, заходи інформаційного протиборства, економічні санкції, використання настроїв населення;

Інші особливості воєнних аспектів сценаріїв протидії наведені в табл. 1.

Особливості воєнних аспектів сщенаріїв протидії гібридній війні

\begin{tabular}{|c|c|c|}
\hline $\begin{array}{c}\text { Характеристики } \\
\text { сценаріїв }\end{array}$ & Гібридна війна & $\begin{array}{c}\text { Традиційна (регулярна) } \\
\text { війна }\end{array}$ \\
\hline Правова база & Відсутня (неконвенційні) & Міжнародне право (конвенційні) \\
\hline Сфери протиборства & $\begin{array}{c}\text { Політична, воєнна, економічна, } \\
\text { інформаційна, міжнародно-правова }\end{array}$ & Політична, воєнна \\
\hline Супротивник & Невизнаний & Визнаний \\
\hline Дiї & Асиметричні, гібридні & Симетричні \\
\hline Фази & Нелінійні, паралельні & Лінійні, послідовні \\
\hline Сценарії & $\begin{array}{c}\text { Сдиний сценарій за всіма сферами } \\
\text { протиборства і фазами конфлікту }\end{array}$ & Сдиний сценарій в межах однієї фази \\
\hline Рівні & Геополітичний, воєнно-стратегічний & Тактичний, оперативний, стратегічний \\
\hline Часові рамки & Необмежені & Обмежені \\
\hline Мета & $\begin{array}{c}\text { Зміна конституційної влади, зовнішнє } \\
\text { управління у воєнно-політичній } \\
\text { i економічній сферах } \\
\end{array}$ & Захоплення території, влади \\
\hline Характер протистояння & Локальний, регіональний & Локальний \\
\hline Введення воєнного стану & Необов'язкове & Обов'язкове \\
\hline Територія & Буферні і “сірі” зони & Обмежена (локалізована) \\
\hline
\end{tabular}




\begin{tabular}{|l|c|c|}
\hline $\begin{array}{c}\text { Характеристики } \\
\text { сценаріїв }\end{array}$ & Гібридна війна & $\begin{array}{c}\text { Традиційна (регулярна) } \\
\text { війна }\end{array}$ \\
\hline Склад сил & Військові, іррегулярні та цивільні суб'єкти & Регулярні військові формування \\
\hline Планування & Паралельне за всіма сферами & Послідовне \\
\hline
\end{tabular}

Сиенарії протидії гібридній війні будуються 3 урахуванням нелінійної конфігурачії атакуючих сил $i$ засобів $i$ відповідності таким критеріям: знецінення ресурсів, які має суб'єкт протиборства, внаслідок втрати політичної, воєнної, економічної інформаційної і правової якості цих ресурсів; здатність швидко реагувати на конфлікти, нелінійний характер яких дає змогу досягати значних результатів за відносно невеликих початкових впливах; перехід від забезпечення безпеки в політичній, економічній, соціальній, культурній сферах держави до функціонального контролю над найважливішими стратегічними елементами кожної сфери; забезпечення можливості оперативного зосередження критично важливих зусиль i ресурсів на найзагрозливішому напрямку; забезпечення комплексної протидії сепаратистським режимам і силам, які їх підтримують; ведення безперервної розвідки і іiі тісний контакт зі структурами політичного i військового управління державою; наявність кадрового pecypcy, здатного забезпечити розроблення i реалізацію сценаріїв протидії гібридній війні; оптимального співвідношення воєнних i невоєнних засобів боротьби.

Отже, для врахування i планування реагування на особливості воєнних аспектів гібридній війні, доцільно сценарії протидії доповнити багатопрофільною інтегрованою операцією військових і невійськових сил та засобів, яка включає військові заходи прихованого характеру, дії сил спеціальних операцій, заходи інформаційного протиборства, економічні санкції, використання настроїв населення.

Оцінювання результативності сценарїв протидї гібридній війні (war weary) також має певні особливості та визначається через знецінення ресурсів, які має суб'єкт протиборства, внаслідок втрати політичної, воєнної, економічної інформаційної і правової якості цих ресурсів. Для гібридної війни як багатовимірного та розрахованого на тривалий період конфлікту, значення результативності має особливе значення. Як правило, відокремлюють три групи результативності протидії: фізичну, моральну, економічну. Фізична результативність визначається через зниження стану та обсягу ресурсів, живої сили, зброї, воєнної техніки та технологій, які використовуються або знаходяться у резерві. У широкому сенсі фізична результативність стосовно живої сили та технологій пов'язана 3 впливом багатьох факторів гібридної війни.

Як приклад, розглянемо результативність умовного сценарію протидії, який включає сім окремих операцій (рис. 2). Результат оцінювання воєнних операцій 2-7 наведено за даними Командування сил спеціальних операцій CША і RAND [6, 7], а для сценарію 1 визначений як відсоток від вкладу всіх інших операцій (дій).

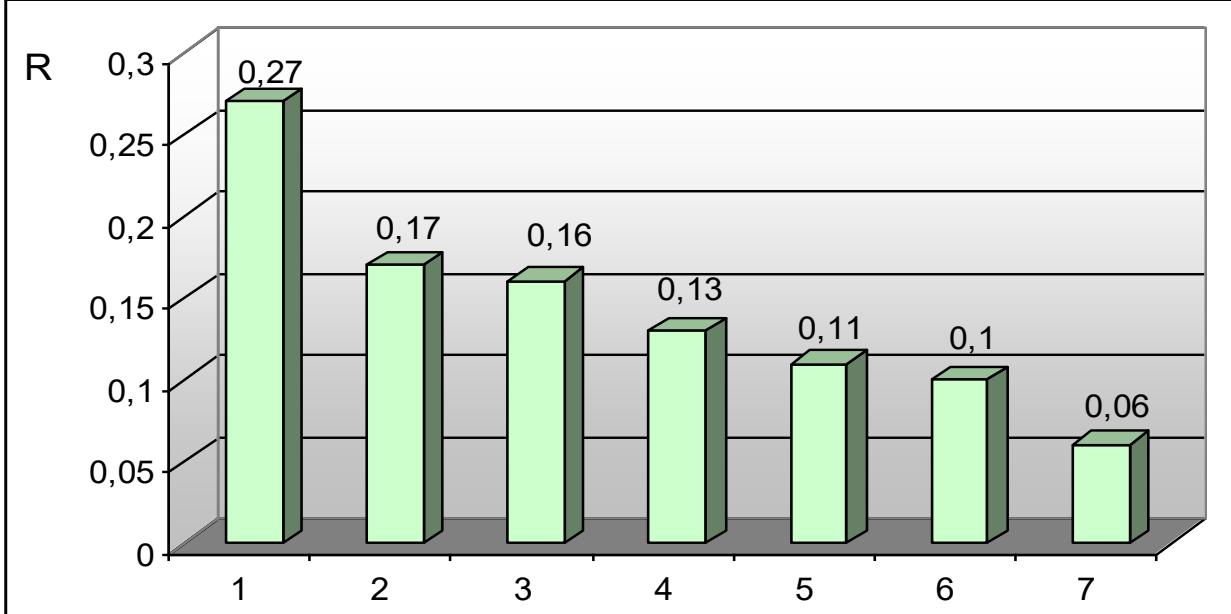

1 - багатопрофільна інтегрована операція військових і невійськових сил та засобів (співвідношення 40:60 \%);

$\mathbf{2}$ - операція об'єднаних сил оборони; $\mathbf{3}$ - дії сил спеціальних операцій;

4 - міжнародна (коаліційна) воєнна допомога; 5 - миротворча операція за мандатом $\mathrm{OOH}$;

6 - територіальна оборона; 7 - загальновійськова операція.

Рис. 2. Результативність воснних аспектів сценаріїв протидії у гібридній війні (за воснно-політичний і економічний контроль) 
Результативність того же сценарію у регулярній війні наведена на рис. 3 [6]. У цьому разі за результативність може бути прийнятий успіх у звільненні тимчасово окупованої території.

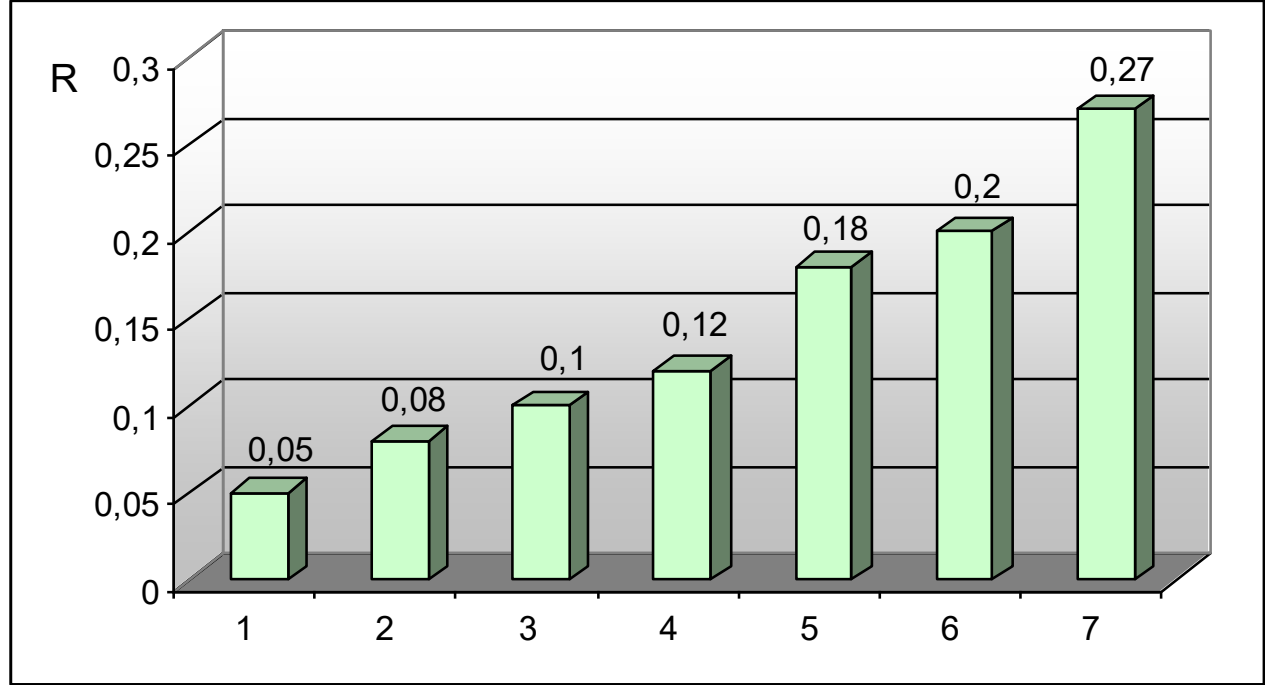

1 - багатопрофільна інтегрована операція військових і невійськових сил та засобів (співвідношення 40:60 \%);

2 - операція об'єднаних сил; 3 - дії сил спеціальних операцій;

4 - міжнародна (коаліційна) воєнна допомога; 5 - операція міжнародних сил за мандатом $\mathrm{OOH}$;

6 - територіальна оборона; 7 - загальновійськова операція.

Рис. 3. Результативність сценаріїв протидії у регулярній війні (за території і ресурси)

\section{Висновки}

1. Введення і використання терміна “гібридна війна" потребує нових підходів до оцінювання i оперативного реагування на зміни воєнно-політичної обстановки, пов'язані 3 традиційними i гібридними загрозами міжнародній і національній безпеці.

2. Успішна адаптація системи національної безпеки і оборони до викликів $\mathrm{i}$ загроз, що породжуються війнами нового типу, залежить від здатності сформувати теоретичні засади війн нового типу, визначити на їх основі стратегію і сценарії протидії, пріоритети розвитку збройних сил, економіки, інформаційної та правової сфер.

3. Під час проведення оборонного планування і визначенні сценаріїв протидії гібридній війні враховуються результати оцінювання воєнно-політичної обстановки, зовнішні та внутрішні фактори, особливості протидії та сукупність показників, яким вони мають відповідати.

4. Для врахування всіх особливостей, доцільно сценарії протидії доповнити багатопрофільною інтегрованою операцією військових і невійськових сил та засобів.

$\begin{array}{clc}5 . \text { Успіх } & \text { протидії гібридній війні } \\ \text { військовій } & \text { сфері } & \text { залежить } \\ \text { від }\end{array}$ результативності визначеного сценарію, в окремих випадках проведення багатопрофільної інтегрованої операції військових i невійськових сил та засобів, операції об'єднаних сил матимуть найбільшу результативність, значний вклад у результативність сценаріїв протидії вносять дії сил спеціальних операцій, міжнародна воєнна допомога.

У подальших дослідженнях буде продовжено теоретичне обгрунтування i удосконалення воєнних аспектів сценаріїв протидії гібридній війні.

\section{СПИСОК ВИКОРИСТАНОЇ ЛІТЕРАТУРИ}

1. Іващенко А. М., Павліковський А. К. Аналіз основних напрямків розвитку оперативних спроможностей Північноатлантичного Альянсу після Варшавського саміту. Збірник наукових праць ЦВСД НУОУ. - К.: НУОУ, 2016. - № 3(58).

2. Іващенко А. М. Мета i напрямки діяльності Північноатлантичного Альянсу 3 підтримки сектору безпеки i оборони країн-партнерів. Збірник наукових праць ЦВСД НУОУ. - К.: НУОУ, 2018. - № 1(62). - С. 41-45.

3. Іващенко А. М. Еволюція поглядів на стратегію сучасного гібридного конфлікту та сценарії протидії гібридним загрозам. Збірник наукових праць ЦВСД НУОУ. - К.: НУОУ, 2015. № 1(53). - C. 18-23.

4. The Military Balance 2015. Editor's Introduction. URL: $\quad$ https://www.iiss.org/en/publications/ military\%20balance/issues/the-military-balance-20155ea6/mb2015-00b-foreword-eff4].

5. Сиротенко А. М., Іващенко А. М. Інформаційна система управління оборонним плануванням на спроможностях J-DARTS i можливості iii впровадження у Збройних Силах України. Наука i оборона, № 4, 2018, С. 29-34.

6. Ball T. Replaced Security Force Assistance Brigades vs. Special Forces. War on the Rocks, № 2, 2017.

7. Chivvis C. S. Understanding Russian "Hybrid Warfare" and What Can be Done (testimony). The RAND Corporation, 2017, $10 \mathrm{p}$. 


\section{Иващенко А. М. к.т.н., доцент;}

Семененко В. М. к.т.н., с.н.с.;

\section{Полякова Е. В.}

Центр военно-стратегических исследований Национального университета обороны Украины имени Ивана Черняховского, Киев

\section{Оценка сценариев противодействия гибридной войне в военной сфере}

Резюме. Исследуются отдельные сценарии противодействия гибридной войне в военной сфере и контексте полного спектра операций.

Ключевые слова: войны нового типа; гибридные войны; противодействие; оборонное планирование; полный спектр операций; сценарии; результативность.

\section{A. Ivashenko, PhD (Technical), assistant professor; \\ V. Semenenko, PhD (Technical), senior researcher; \\ E. Poljakova}

Center for Military and Strategic Studies of the National Defence University of Ukraine named after Ivan Cherniakhovskyi, Kyiv

\section{Evaluation of scenarios of countering a hybrid war in the military sphere}

Resume. Separate scenarios of combating a hybrid war in the military sphere and the context of the full range of operations are investigated.

Keywords: wars of the new type; hybrid wars; counteraction; defense planning; full range of operations; scenarios; effectiveness. 